\title{
Recent Occurrence of Fusarium oxysporum f. sp. cubense Tropical Race
} 4 in Asia

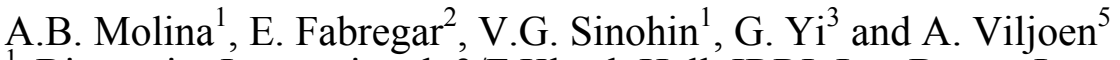 \\ ${ }_{1}$ Bioversity International, 3/F Khush Hall, IRRI, Los Banos, Laguna, Philippines \\ 2 Lapanday Foods Corporation, Davao City, Philippines \\ 3 Institute of Fruit Tree Research, Guangdong Academy of Agricultural Science, Tianhe \\ District, Guangzhou City 510640, GuangDong Province, China \\ 4 Forestry and Agricultural Biotechnology Institute (FABI), University of Pretoria, South \\ Africa \\ 5 Department of Plant Pathology, University of Stellenbosch, Private Bag X1, Matieland \\ 7602, South Africa
}

Keywords: Australia, Cavendish cultivars, China, Fusarium wilt, Indonesia, Malaysia, Philippines

\begin{abstract}
Fusarium wilt, caused by Fusarium oxysporum f. sp. cubense (Foc), is an important disease of banana in almost all banana-producing countries of the world. The recent occurrence of a highly virulent form of Foc in Asia, known as 'tropical race 4' (TR4), presents an imminent threat to the region's Cavendish-based banana industries. Foc-TR4 has caused severe damage to the Cavendish banana industry of Taiwan since 1967, destroyed new plantations of Cavendish banana in Indonesia and Malaysia since the early 1990 s and caused field epidemics in the Northern Territory of Australia between 1997 and 1999. In 2004, severe Foc infection in banana plantations in Guangdong province, South China, heightened the TR4 threat. All outbreaks are associated with the vegetative compatibility group (VCG) complex 1213/16. Historical field observations of Foc in Cavendish banana cultivars in the Philippines since 1970 are described. More than 30,000 individual reports of infection were officially recorded in the Philippines from 1974 to 1991. These infections were tested and identified as VCG 0122, 0123 and 0126, which are believed to be less virulent than the VCG 01213/16 complex. In September 2006, 30 infected plant samples were collected from highland and lowland Cavendish banana farms in Davao. These samples confirmed that the recent outbreaks of Fusarium wilt in Cavendish in the Philippines were caused by the VCG 01213/16 complex. The Philippine government, private banana companies and Bioversity International are collaborating to manage the disease and to try to contain further spread of Foc-TR4.
\end{abstract}

\section{INTRODUCTION}

Fusarium wilt, caused by Fusarium oxysporum f. sp. cubense (Foc), is a major concern of the global banana industry. The devastating disease destroyed 'Gros Michel' (AAA genome) plantations in the Central American/Caribbean region in the 1950s and lead to the disappearance of the cultivar as the traditional export banana. Cavendish cultivars (AAA genome), which are resistant to Foc race 1 that attacks 'Gros Michel', were used as replacements. Today, Cavendish cultivars are the mainstay of the world's banana export industries.

The recent occurrence of a virulent form of Foc in Asia that affects Cavendish banana cultivars in the tropics presents a serious new threat. This new form of Foc belongs to the vegetative compatibility group (VCG) 01213/16 and has been associated with severe field epidemics in Indonesia and Malaysia. Referred to as 'tropical race 4' (TR4), this pathogen has been observed in several countries in Asia where Cavendish banana cultivars are important for local consumption and export. In addition, all banana cultivars that are susceptible to Foc races 1 and 2 also succumb to TR4.

It is believed that Foc has co-evolved with banana in Asia and that Foc-TR4 is endemic in this part of the world. This paper will review the historical occurrences of 
Foc-TR4 in Asia, and present evidence of its recent occurrence in China and the Philippines, where Cavendish banana cultivars are of great economic importance.

\section{HISTORICAL OCCURRENCES}

\section{Taiwan}

The Taiwan banana industry is a Cavendish-based production system. In the 1960s, Taiwan had about 50,000 hectares of banana plantations and was originally the major banana exporter to Japan. The first Foc epidemic affecting Cavendish banana plantations in Taiwan was reported in 1967 (Su et al., 1986), and the decline of the industry started in the 1970s. The high cost associated with disease management and the substantial losses in yield significantly increased production costs and negatively affected Taiwan's competitiveness in the export business. Today, only about 6000 ha of Cavendish plantations remain, of which 4000 ha are heavily infested by Foc (Hwang and Ko, 2004). While other VCGs are found in Taiwan, the recent identification of VCG 01213/16 is alarming as southern Taiwan has tropical conditions favourable for epidemic development during most of the growing period (Ploetz, 2005). Taiwan managed to save its banana industry by the development of an integrated disease management approach, including the use of disease-free tissue-culture planting materials, annual cropping and selection of somaclonal resistant varieties (Hwang and Ko, 2004). Several Foc-TR4 resistant Cavendish somaclones have been identified and commercialised, including 'Formosana' and 'GCTCV-119'. Despite a certain level of success, Foc continues to be a significant production burden for the Taiwan banana industry.

\section{Indonesia and Malaysia}

Diversity of Foc is high in Indonesia and Malaysia. Although Foc-TR4 may have been present in Indonesia and Malaysia for very many years (and is possibly endemic in the Indo-Malayan region, which lies in the center of origin of Musa), its economic importance did not become evident until the early 1990s (Djatnika and Sutanto, 2002; Lee et al., 2001; Nurhadi et al., 1994). During this period, Chiquita and Del Monte Corporation established commercial Cavendish plantations in these countries to take advantage of the rich soil, favourable climate and cost-effective manpower to supply the expanding markets in East Asia and the Middle East. Many of these farms were established on cleared forest land. Just 2 years after establishment, these farms were destroyed by Foc, which was identified to belong to VCG 01213/16 (Ploetz and Pegg, 2000). This VCG is believed to have spread within Indonesia through movements of infected planting materials by traders and migrating growers. It is now found on the islands of Sumatra, Java, Sulawesi, Halhamera and recently in the province of Papua (formerly Irian Jaya) near the border with Papua New Guinea (Davis et al., 2000; Shivas and Philemon, 1996). In Malaysia, Foc-TR4 is still only found in the peninsular (Davis et al., 2000; Ploetz and Pegg, 2000). Foc-TR4 is a serious production constraint for Cavendish growers supplying the local markets of Indonesia and Malaysia. In Lampung District of Sumatra alone, Fusarium wilt cost small-scale farmers US\$ 9-11 million in yield losses between 1993 and 2002 (Nurhadi et al., 1994). About 5000 ha of Cavendish plantations developed for export have been totally abandoned. Recently, however, about 800 ha were replanted with resistant Cavendish somaclones from Taiwan. Less than $10 \%$ infection has been observed in these new plantings, which is good enough to sustain production for the local market.

\section{Australia}

Fusarium wilt of banana was first described in Australia in 1874 on 'Sugar' (AAB genome, syn. 'Silk') (Pegg et al., 1996). Later, it became a problem in plantations of 'Lady Finger' (AAB genome, Pome subgroup), but the majority of commercial plantings were of Cavendish cultivars, which are resistant to Foc race 1. Some Cavendishcompetent Foc VCGs (VCG 0120, 01291, 01211) were reported as early as 1993 in the 
subtropical banana-growing areas of South Queensland and New South Wales (Moore et al., 2001; Pegg et al., 1996). These VCGs belong to race 4, but are less virulent than the Foc-TR4 in that they only attack Cavendish cultivars stressed by environmental conditions, such as cold weather (Moore et al., 2001; Pegg et al., 1996).

Foc-TR4 infections were detected between 1977 and 1999 in three sites near Darwin in the Northern Territory where Cavendish cultivars are grown in tropical conditions (Conde and Pitkethley, 2001). Bentley and her co-workers identified the pathogen as that of VCG 01213/16 (Bentley et al., 2001). Using DNA fingerprint comparison with isolates from other countries, they concluded that the pathogen did not originate in Australia, but was introduced by way of man's activities. The strict implementation of quarantine policies has prevented the further spread of TR4 to the major Cavendish plantations in North Queensland.

\section{RECENT OCCURRENCES}

\section{China}

The last decade has seen a tremendous expansion of Cavendish plantations in southern China to meet an increasing demand for local fruit as a result of the country's rapid economic growth. At present, China is the world's fourth largest banana producer. About 91\% of bananas produced in China are from Cavendish cultivars. In 2001, Foc symptoms were observed on Cavendish plants in localised areas along the Pearl River Delta in Guangdong Province (Xu et al., 2003), the major banana-producing region in China. The Foc isolates responsible for the outbreak were identified as VCG01213/16 (Chen et al., 2005a; Huang et al., 2005). It is believed that the pathogen may have been introduced from Taiwan as a result of movements of planting materials by growers and traders, and the lack of strict quarantine regulations.

In a survey conducted in 2006, it was reported that about 6700 ha of banana plantings were severely affected in the Panyu district and Zhongshen city in Guangdong province (Yi et al., 2007). In addition to attacking Cavendish cultivars, Foc-TR4 was also affecting the popular local variety 'Fenjiao' (ABB genome, syn. 'Pisang Awak') (Chen et al., 2005a). Samples from recent infections in southern China were collected by the Pomology Research Institute, Guangdong Academy of Agricultural Sciences, Guangzhou, China, and sent to the Forestry and Agricultural Biotechnology Institute (FABI) at the University of Pretoria in South Africa for VCG analyses using the technique described by Puhalla (1985). Unpublished results confirmed that the pathogen involved is Foc-TR4.

Fusarium wilt is now spreading to other banana-growing districts in southern China, including the island province of Hainan (Yi et al., 2007). The Chinese agricultural agencies are implementing measures to prevent further spread of the disease. Appropriate management practices have also been developed. Bioversity International is collaborating with the Pomology Research Institute to carry out extensive disease surveys and characterise Foc VCGs in southern China, and to implement rational quarantine policies and programmes.

\section{Philippines}

Fusarium wilt was reported in Cavendish plantations in the Philippines as early as the 1970s (Magnaye, 2001), and more than 30,000 affected plants were eradicated between 1974 and 1991 (Table 1). The outbreaks were caused by Foc VCGs 0122, 0123 and 0126 and were often associated with water logging. In 2002, an outbreak of Fusarium wilt was observed in a newly planted Cavendish banana farm at Calinan in Davao in an area 350-500 $\mathrm{m}$ above sea level. The area was previously under 'Lakatan' (AAA genome), a popular dessert cultivar, but plantings had been abandoned due to severe Fusarium wilt. Without pathogen identification and VCG analyses, it was thought that Foc race 1 may have been responsible. However, in 2004-2005, Fusarium wilt was observed in some traditional lowland Cavendish farms about $25 \mathrm{~m}$ above sea level in the same area. The new infections were more aggressive than previous ones and spread 
rapidly, suggesting that Foc-TR4 may have been the cause. Thirty samples were collected from highland and lowland Cavendish banana farms in Davao from September to December 2005 and sent to FABI for VCG analyses. The results showed that all infections were caused by Foc VCG $01213 / 16$. This finding was highly significant as the Philippines has been the leading banana exporting country in Asia since the late 1960s. In 2006, the country registered its highest export volume of 2 million metric tons, thereby becoming the world's second largest banana exporter. Because of the importance of export bananas to the Philippine economy and locally grown bananas to the food security of the nation, the Philippine government, private banana companies and Bioversity International are closely collaborating to manage the disease and prevent the further spread of Foc-TR4.

\section{THREAT TO OTHER ASIAN COUNTRIES}

The geographic distribution of Foc-TR4 in Asia and its potential to devastate banana plantations pose a serious threat to banana production in other countries in the region. It is believed that Foc-TR4 may be endemic to Indonesia, Malaysia and possibly the Philippines. However, the pathogen appears to have been introduced into the Northern Territory of Australia and southern China. There are no reports of the occurrence of FocTR4 in other major banana-growing countries in Asia, including India (Thangavelu et al., 2001), the world's largest banana-producing country. While the pathogen may not have been reported in these countries, systematic surveys have not been undertaken recently. Foc-TR4 has, for instance, not been reported from Papua New Guinea (PNG), but VCG 01213/16 has been found in nearby Papua (formerly Irian Jaya, a province of Indonesia). The movement of Foc-TR4 may follow the route of Foc race 1 and thus pose a serious threat to small-scale growers in PNG. Many indigenous cultivars grown by subsistence farmers in PNG would undoubtedly be susceptible to the disease, so the potential spread of Foc-TR4 represents a threat both to food security and to the country's unique banana biodiversity.

\section{PRESENT EFFORTS TO MITIGATE THE SPREAD AND DAMAGE CAUSED BY FOC TR4 IN ASIA}

The Banana Asia Pacific Network (BAPNET) of Bioversity International has initiated a regional collaboration to survey the distribution of Foc VCGs in Asia and the Pacific through funding provided by the Australian Centre for International Agricultural Research (ACIAR) and the region's national programmes. The objective is to develop a distribution map of Foc VCGs and to list the cultivars each VCG affects in each country. This activity will provide a rational basis for developing and implementing quarantine policies within and among countries. Concurrently, control tactics are being developed and validated, including improved production systems by adapting the experience of Taiwan in the successful use of tissue culture, and the selection and use of resistant somaclonal variants. Banana cultivars included in the International Musa Testing Programme (IMTP) of Bioversity International are being evaluated throughout the region through the National Repository Centres of each BAPNET-member country. Some FHIA cultivars and somaclonal variants of Cavendish provided by the Taiwan Banana Research Institute are tolerant to Foc-TR4 (Chen et al., 2005b; Huang et al., 2005). Bioversity International and its partners are taking a holistic approach in managing Fusarium wilt in the region that includes prevention, exclusion, cultural management and the appropriate use of cultivar resistance and diversity.

\section{Literature Cited}

Bentley, S., Moore, N.Y., Pegg, K.G., Gerlach, K.S. and Smith, L.J. 2001. Genetic characterisation and detection of Fusarium wilt. p.143-151. In: A.B. Molina, N.H. Nik Masdek and K.W. Liew (eds.), Banana Fusarium Wilt Management: Towards Sustainable Cultivation. Proceedings of the International Workshop on the Banana 
Fusarium Wilt Disease held in Genting Highlands Resort, Malaysia, 18-20 October 1999. INIBAP, Los Baños, Laguna, Philippines.

Chen, H.B., Xu, C.X., Feng, Q.R., Hu, G.B., Li, J.G., Wang, Z.H. and Molina, A.B. 2005a. Screening of banana clones for resistance to fusarium wilt in China. p.165-174. In: A.B. Molina, V.N. Roa, I. Van den Bergh and K.H. Borromeo (eds.), Advancing Banana and Plantain R\&D in Asia and the Pacific - Vol. 13. Proceedings of the $3^{\text {rd }}$ BAPNET Steering Committee meeting held in Jakarta, Indonesia, 6-9 October 2003. INIBAP, Los Baños, Laguna, Philippines.

Chen, Y.Y., Wei, S.X. and Zhang, L. 2005b. Status of banana R\&D in Hainan, China. p.193-201. In: A.B. Molina, V.N. Roa, I. Van den Bergh and K.H. Borromeo (eds.), Advancing Banana and Plantain R\&D in Asia and the Pacific - Vol. 13. Proceedings of the $3^{\text {rd }}$ BAPNET Steering Committee Meeting held in Jakarta, Indonesia, 6-9 October 2003. INIBAP, Los Baños, Laguna, Philippines.

Conde, B.D. and Pitkethley, R.N. 2001. The discovery, identification and management of banana Fusarium wilt outbreaks in the Northern Territory of Australia. p.260-265. In: A.B. Molina, N.H. Nik Masdek and K.W. Liew (eds.), Banana Fusarium wilt Management: Towards Sustainable Cultivation. Proceedings of the International Workshop on the Banana Fusarium Wilt Disease held in Genting Highlands Resort, Malaysia, 18-20 October 1999. INIBAP, Los Baños, Laguna, Philippines.

Davis, R.I., Moore, N.Y., Bentley, S., Gunua, T.G. and Rahamma, A. 2000. Further records of Fusarium oxysporum f. sp. cubense from New Guinea. Australasian Plant Pathology 29:224.

Djatnika, I. and Sutanto, A. 2002. Current research activities on banana disease and pests in Indonesia. p.93-98. In: A.B. Molina, J.E. Eusebio, V.N. Roa, I. Van den Bergh and A.G. Maghuyop (eds.), Advancing Banana and Plantain R\&D in Asia and the Pacific Vol. 11. INIBAP, Los Baños, Laguna, Philippines.

Huang, B.Z., Xu, L.B. and Molina, A.B. 2005. Preliminary evaluation of IMTP-III varieties and local cultivars against Fusarium wilt disease in southern China. p.187191. In: A.B. Molina, V.N. Roa, I. Van den Bergh and K.H. Borromeo (eds.), Advancing Banana and Plantain R\&D in Asia and the Pacific - Vol. 13. Proceedings of the $3^{\text {rd }}$ BAPNET Steering Committee Meeting held in Jakarta, Indonesia, 6-9 October 2003. INIBAP, Los Baños, Laguna, Philippines.

Hwang, S.C. and Ko, W. 2004. Cavendish banana cultivars resistant to Fusarium wilt acquired through somaclonal variation in Taiwan. Plant Dis. 88:580-588.

Lee, Y.M., Teo, L. and Ong, K.P. 2001. Fusarium wilt of Cavendish banana and its control in Malaysia. p.252-259. In: A.B. Molina, N.H. Nik Masdek and K.W. Liew (eds.), Banana Fusarium Wilt Management: Towards Sustainable Cultivation. Proceedings of the International Workshop on the Banana Fusarium wilt Disease held in Genting Highlands Resort, Malaysia, 18-20 October 1999. INIBAP, Los Baños, Laguna, Philippines.

Magnaye, L.V. 2001. Status of Panama disease in the Philippines. p.50-57. In: A.B. Molina, N.H. Nik Masdek and K.W. Liew (eds.), Banana Fusarium Wilt Management: Towards Sustainable Cultivation. Proceedings of the International Workshop on the Banana Fusarium Wilt Disease held in Genting Highlands Resort, Malaysia, 18-20 October 1999. INIBAP, Los Baños, Laguna, Philippines.

Moore, N.Y., Pegg, K.G., Smith, L.J., Langdon, P.W., Bentley, S. and Smith M.K. 2001. Fusarium wilt of banana in Australia. p.64-75. In: A.B. Molina, N.H. Nik Masdek and K.W. Liew (eds.), Banana Fusarium Wilt Management: Towards Sustainable Cultivation. Proceedings of the International Workshop on the Banana Fusarium Wilt Disease held in Genting Highlands Resort, Malaysia, 18-20 October 1999. INIBAP, Los Baños, Laguna, Philippines.

Nurhadi, M. Rais and Harlion. 1994. The disease incidence of bacterial and Fusarium wilt disease in Lampung province. Indonesian Info. Hort. 2(1):35-37.

Pegg. K.G., Moore, N.Y. and Bentley, S. 1996. Fusarium wilt of banana in Australia. Australian Journal of Agricultural Research. 47:637-650. 
Ploetz, R.C. 2005. Panama Disease: An Old Nemesis Rears its Ugly Head (Part 1: The Beginnings of the Banana Export Trades), ASPNet Feature Story, August 2005.

Ploetz, R.C. and Pegg, K.G. 2000. Fusarium wilt. p.143-159. In: D.R. Jones (ed.) Diseases of Banana, Abacá and Enset. CABI Publishing, Wallingford, UK.

Puhalla, J.C. 1985. Classification of strains of Fusarium oxysporum on the basis of vegetative compatibility. Canadian Journal Botany 63:179-183.

Shivas, R.G. and Philemon, E. 1996. First record of Fusarium oxysporum f. sp. cubense on banana in PNG. Australasian Plant Pathology 25:260.

Su, H.J., Hwang, S.C. and Ko, W.H. 1986. Fusarium wilt of Cavendish bananas in Taiwan. Plant Disease 70:814-818.

Thangavelu, R., Sundararaju, P., Sathiamoorthy, S., Reghuchander, T., Velazhahan, R., Nakkeeran, S. and Palanisamy, A. 2001. Status of Fusarium wilt of banana in India. p.58-63. In: A.B. Molina, N.H. Nik Masdek and K.W. Liew (eds.), Banana Fusarium Wilt Management: Towards Sustainable Cultivation. Proceedings of the International Workshop on the Banana Fusarium Wilt Disease held in Genting Highlands Resort, Malaysia, 18-20 October 1999. INIBAP, Los Baños, Laguna, Philippines.

Xu, L.B., Huang, B.Z. and Wei, Y.R.. 2003. Production and banana R\&D in China. p.7780. In: A.B. Molina, J.E. Eusebio, V.N. Roa, I. Van den Bergh and M.A.G. Maghuyop (eds.), Advancing Banana and Plantain R\&D in Asia and the Pacific - Vol. 11. Proceedings of the $1^{\text {st }}$ BAPNET Steering Committee Meeting held in Los Baños, Laguna, Philippines 7-10 October 2002. INIBAP, Los Baños, Laguna, Philippines.

Yi, G.J., Huang, B.Z., Xu, L.B., Chen, H.B., Hu, G.B., Xu, C.X. and Molina, A.B. 2007. Fusarium wilt threatens livelihoods of banana farmers in Southern China. p.1-2. In: A.B. Molina, J.T. Oliver, V.N. Roa and V.G.O. Sinohin (eds.), RISBAP Bulletin (July 2007) Volume 11, No. 2. Bioversity International Regional Office for Asia and the Pacific, Los Baños, Laguna, Philippines. 


\section{Tables}

Table 1. Fusarium-wilt infected plants eradicated from 1974 to 1991 in 12 commercial Cavendish plantations in Davao, Philippines. Source: Magnaye (2001).

\begin{tabular}{lcc}
\hline Year & Total number of cases & Average number of cases per month \\
\hline 1974 & 516 & 51.7 \\
1975 & 854 & 71.2 \\
1976 & 1,112 & 92.7 \\
1977 & 1,026 & 85.5 \\
1978 & 1,091 & 90.9 \\
1979 & 1,723 & 143.6 \\
1980 & 1,534 & 127.8 \\
1981 & 1,078 & 89.8 \\
1982 & 1,271 & 105.9 \\
1983 & 776 & 64.7 \\
1984 & 895 & 74.6 \\
1985 & 1,790 & 149.2 \\
1986 & 2,535 & 211.3 \\
1987 & 2,559 & 213.3 \\
1988 & 3,152 & 262.7 \\
1989 & 3,540 & 303.3 \\
1990 & 3,190 & 265.8 \\
1991 & 3,597 & 299.8 \\
\hline Total & 32,239 & 150.2 \\
\hline
\end{tabular}


